\title{
ACERCAMIENTOS A LA OBRA DE ROBERTO BRENES MESEN
}

\author{
POR
}

\author{
FAUSTINO CHAMORRO GONZALEZ \\ Universidad Nacional, Costa Rica
}

Pero ninguno de los hombres vino para decirme que en mi voz amaba el diáfano cristal del alma mía («Crisoralia») ${ }^{1}$.

Si en el Saber, la Ciencia, la Religión y la Literatura, en su dimensión de universales y trascendentes, libres de pétreos anquilosamientos y de barrotes dogmáticos, existiese catálogo de santos, sin duda alguna el nombre de San Roberto Brenes Mesén ocuparía un lugar.

Cualquier crítico de moda, de esos que, en su labor analizadora e interpretativa del texto, se deslizan encarrilados por los fríos rieles de un método (cualquiera) en marcha unidireccional, puede apartar la vista del presente ensayo, que sin ambages ni complicados metalenguajes manifiesta sincera y cristalinamente desde el comienzo el calor humano con que se propone abordar la comprensión de la obra brenesmesénica. El camino, cuando se pretende penetrar en el bosque de una creación literaria con la cálida intención del explorador que descubre viviendo y vive descubriendo, no se traza de antemano. La intuición, impulsada por la ineludible fuerza de un lenguaje-texto sin explorar, será el único «marco teórico» para, sobre la marcha, descubrir el «odos», la vía que salvará el abismo existente entre las preconcepciones sistematizadoras y la siempre nueva, reciente e irrepetible voz que anima la obra literaria abordada.

Quiero, pues, penetrar en la obra de Roberto Brenes Mesén con la simpatía y magnetismo que cuando leo con los ojos del espíritu sus estancias, poemas y ensayos, invaden mi ser al lograr traspasar la seductora

${ }^{1}$ Roberto Brenes M., Poemas de amor y de muerte (San José: Imprenta Española Soley y Valverde, 1944), p. 71. 
porcelana de sus urnas literarias; quiero abrir su obra, agitado en la ebullición electromagnética relampagueante que, cual hechizo interior, me lanza con la atención de potente sagitario hacia otras esferas trascendentes, cuya existencia no cosificada las hace intangibles para los pedestres métodos de un burdo empirismo clasificador y cajonero. Quiero abordar al cantor de Arión y su canto, en la terrible instantánea de su salto al pielago inmenso, y perseguirlo a la velocidad del delfín, que en la bramadora soledad del Ponto lo conduce hacia las costas lejanas de Corinto, escuchando la armoniosa melodía interior de su palabra fluyente en concierto con el infinito silencio, con el espacio sin horizonte y con el rugido del mar. Si en este atrevido propósito naufrago, al menos habré conseguido que los ojos seguidores de estas líneas prueben, gusten, sientan el calor brenesmesénico; su soledad como existencia, la infinitud aparentemente limitadora de la urna humana; las lágrimas saladas de su llanto silencioso; sus ansias, tan anchas como el mar sin horizontes y tan luengas como la distancia que salva el límite abisal y la profundidad no alcanzable del eterno éter. Porque si, aunque sea a distancia, Ilego a vislumbrar la brumosa costa de Corinto o la Beatriz que persigue el cantor, también tú, lector, en un trío silencioso conmigo junto al poeta, te verás arrebatado por un «Relámpago divino»:

Esta mañana levanté mi mente como un ánfora azul hecha en zafiro en demanda de luz para mi vida, y se llenó de luz y de infinito.

Desde entonces el árbol de mi vida se ha poblado de cantos y de trinos y bástame mirar el alma mía para sentir vibrando ese infinito.

Sé cosas nuevas que aprendí mirando en mi interior, como en abierto libro, y soy más fuerte y más alegre y siento dentro de mí un relámpago divino².

Y porque, según nuestro autor, «ninguna obra de arte se analiza sin destruirla», trataré de proseguir como un visionario arrastrado por «esa

${ }^{2}$ Roberto Brenes M., Poesías de Roberto Brenes Mesén (San José: Editorial Costa Rica, 1979), p. 178. En adelante, cada vez que se cite un poema se hará referencia de título y página, según la obra Poesías de Roberto Brenes Mesén, con prólogo de José Basileo Acuña (San José: Editorial Costa Rica, 1979). 
magia de sugestión que surge más allá del estilo y de la forma», puesto que «es más difícil interesarse en el intrínseco valor artístico de una obra maestra que en la investigación de circunstancias de hecho, bajo el disfraz de Historia Literaria» ${ }^{3}$. Espero, no obstante, poder seguir varios bordones de la multicorde escala de su arpa, como notas fundamentales que invaden con su resonancia ese universo interior literariamente hipostasiado por la tersura de la lengua castellana, dócil y plena en la pluma del escritor.

Que otros escalen oteros, promontorios de la historia, pertrechados para perseguir influencias, fuentes, semejanzas y desemejanzas. Si nuestro autor concebía que «la verdadera literatura sólo tiene que ver con las causas permanentes de los cambios y los hechos, sensibilidad y pensamiento», el pensamiento y la sensibilidad brenesmesénicos, causas últimas de su obra, me apresto a seguir. Porque muy difícil resulta, en el caso que nos ocupa, deslindar alma de autor — no biografía cronológica y contingente- de obra literaria. Sensibilidad y pensamiento se funden sin linderos en un único campo de vida y de palabra:

Las sensaciones repetidas y refundidas en una, generan la imagen. Las diversas imágenes mentales resumidas en una, constituyen el concepto [...]. Sumad conceptos a conceptos extraídos del Universo por medio de la meditación, de la concentración de vuestra mente y de súbito, en un instante divino, ellos se fundirán en el crisol de vuestra mente superior y surgirá la Iluminación de la Conciencia Cósmica. Es un estado de conciencia suprema durante la cual no se argumenta ni se razona: se ve, se sabe, se siente ${ }^{4}$.

A la suprema vibración literaria acude el autor para expresar ese instante divino convertido en el paradójico «Instante eterno»:

Tengo un tesoro escondido en el santuario de mi alma; es un ensueño vivido

bajo una tienda de palma.

Es una dicha encerrada en el botón de una rosa; si la buscáis, no halláis nada, iy está mi dicha en la rosa!

${ }^{3}$ Roberto Brenes M., Crítica americana (San José: Ediciones del Convivio, 1936), p. 185. Las restantes citas textuales breves en el cuerpo del escrito, sin referencia, están tomadas, passim, de las obras de B. M.

${ }^{4}$ El canto de las horas (San José: Colección Ariel, núm. 8, Imprenta Alsina, $\sin$ año), pp. 43 y 44 . 
Es un trino entre palmares de una dulce ave perdida, es un recuerdo de azahares de un instante de otra vida.

¡Tengo un tesoro encerrado! iTengo una dicha escondida! ¿Es el recuerdo adorado del resplandor de otra vida! (p. 190).

El crítico iconoclasta, el místico y el asceta, el científico y el metafísico, el teórico literario y el poeta, destellan en polifacético prisma viviente, forjando su obra, que se manifiesta como concertada tocata-fuga, donde afloran alternativamente alguna o algunas de esas siete cuerdas, cuando no resuenan concomitantes todas ellas. En el magistral retrato que de él ha trazado con vigorosa penetración y aguzada sensibilidad en el prólogo a Poesias de Roberto Brenes Mesén (pp. 8-9), su alumno el poeta José Basileo Acuña, me parece encontrar, como ecos, las voces que tejen su obra literaria; o si se quiere mejor, los trazos de su obra se presentan acordes con los rasgos del retrato:

Era de estatura media, más bien alto que bajo. Vestía con pulcritud y esmero. Los colores de sus trajes eran neutros, con preferencia el gris, a veces tonos oscuros. Sus corbatas eran discretas y armonizaban con su traje. Sus zapatos escrupulosamente limpios. [...] Otra característica que llamaba mucho la atención era el uso que hacía de su cuerpo como un medio de expresión y comunicación. Se movía con soltura y suavidad como quien tiene un perfecto dominio de sus músculos y maneja diestramente su tono muscular. [...] Concordaba con este dominio somático el proteico lenguaje de sus labios, que, siempre amortiguados por cierta piedad magisterial, transmitía desde una serie de ironías duras y finas hasta una ternura compasiva. Asimismo concordaba la cambiante gama de sus miradas, que al parecer él dirigía, en diversos grados de intensidad y profundidad, desde un centro stujetivo que constituía una especie de Sinaí interior; que él velaba para los demás con unos anteojos oscuros que, para sus alumnos y admiradores, se convertían en algo así como una enigmática pantalla detrás de la cual don Roberto observaba «sin ser visto». Pero lo que hacía contraste con la serena euritmia de sus gestos y movimientos corporales eran sus manos. El las agitaba como si fueran tentáculos expresivos de múltiples estados emotivos. Parecían ser traidoras a su dueño y revelar sus hondos sentimientos y la intensidad de sus pasiones, que el dueño mantenía celosamente dominadas por su voluntad férrea. Por sus manos se 
manifestaba su «inconsciente», ese compañero permanente que todos llevamos dentro. Por el resto de su cuerpo se manifestaba, al parecer, 1a «serenidad clásica» (el equilibrio entre la razón y el sentimiento que don Roberto luchaba por mantener en su mundo).

Ascetismo que con férrea voluntad gobierna su somática urna discretamente adornada. Pulcritud, esmero y escrupulosa limpieza, la corteza formal de sus escritos. Con ternura compasiva, con palabra penetrante y con la piedad del maestro, gobierna su pluriexpresiva palabra desde su interior, hervidero desbordante que fluye equilibrado con la serenidad clásica, entre razón y sentimiento.

Cuando uno se aproxima a sus ensayos, siente la caricia de los torneados bordes de las ánforas de sus poemas; cuando se acerca con sigilo, temeroso y como más profano, a sus poemas, encuentra que son la última expresión de sus ensayos, sublimados por el inefable lenguaje del poeta. Lo que el filósofo no alcanza a expresar con el conocimiento discursivo de la palabra, lo consigue - o al menos intenta conseguirlo- con la palabra-inspiración. De ordinario se me ofrece ensayando en poesía o poetizando en ensayo. En este ir y venir, no me atrevería a resolver cuándo son las Horas y los Dioses los que le revelan sabiduría con su presencia o cuándo el ambicioso poeta trata de alcanzar el más alto grado de la Conciencia Cósmica tomando de trampolín su ensayo discursivo para alcanzar las sublimes cimas del Helicón consagrante. Lo que sí no ofrece duda es que en sus ensayos y en su obra poética funciona idéntico motor, capaz de mover el carruaje de la palabra a distintos grados y niveles de movimiento, color y sonido, regidos por un como embrague ínsito en el hálito del escritor. Y él así lo sentía, así lo teorizaba y asimismo inquietamente lo perseguía en sus escritos. «Porque lo que realmente ocurre —escribió - es que a medida que el pensamiento alcanza mayor altura y su presencia despierta la emoción en el artista, aparece el ritmo como aparecen todos los otros elementos de la expresión artística, cesando en absoluto, con ello, la diferencia entre la 'prosa y la poesía'. [...] Ni los puntos de partida en el lenguaje humano, ni los fines ideales, dentro del arte, justifican una especial distinción» ${ }^{5}$. Y concluye manifestando que los términos poesía y prosa y sus respectivos conceptos no son más que otras categorías literarias sin fundamento como las de los géneros, escuelas y demás.

Porque así se aprecia en las repetidas lecturas meditadas de su obra y porque el testimonio convincente de nuestro autor como teórico así lo

${ }^{5}$ Las categorias literarias, obra incluida en María E. Dengo, Roberto Brenes Mesén (San José: Ministerio de Culturra, 1974), pp. 308-310. 
explicita, en estos acercamientos trataré de olvidar vetustas murallas entre prosa y poesía, que han hecho dual la obra de muchos autores. ¿Qué es lo que separa al agua congelada del agua fría? ¿Cuál la diferencia entre el agua fría y la templada, entre la templada y la caliente, entre la caliente y la que hierve, entre el agua que hierve y la vaporosa columna, y entre la vaporosa columna y el agua condensada? Simples estados diferentes de una misma esencia; formas distintas de una misma sustancia, entre las cuales el físico establece divisiones clasificatorias.

La obra brenesmesénica se expande unitaria, sin linderos entre el llano y la ladera, la ladera y la colina, la llanura montañosa y los picos escarpados del sublime Pindo que se cuelga de las nubes voladoras y termina fundiéndose en el éter en busca de la Idea. Desde el llano se puede apreciar mejor la altura de la Idea; y desde las cumbres se ensancha y acrecienta la contemplación de la llanura pensante. La obra de Brenes Mesén ha sido de ordinario contemplada unidimensionalmente desde las crestas simbólicas de sus poemas y desde las talladas formas de su ritmo, de su música y de sus versos, y, como consecuencia, repetitivamente encasillada en el nicho del modernismo como otra producción que hace grupo con las de su época, corriente y escuela. Sin embargo, como él dice, «todo en el universo vibra. No hay una sola excepción en el largo recorrido de la roca a la mente, ni la hay de la mente a lo divino ${ }^{6}$. Así, el universo de su obra es un continuum merced a la persistencia de la idea. A través de la palabra, proteico «cántaro de aire y éter en donde se contiene el ambrosíaco e incorruptible licor del pensamiento» ${ }^{7}$, navega la idea como disfrazada con distinto ritmo, sonido y color. Bien se puede apreciar, a través de los pasajes siguientes, cómo aflora en variados registros el espíritu iconoclasta de Brenes Mesén:

Ansío combatir hombres e ideas... Me propongo discutir la legitimidad de muchas reputaciones y el valor artístico y filosófico de obras y doctrinas ${ }^{8}$.

Vengo de abajo, del polvo que engendra la vida y arroja hacia lo alto las copas de los árboles que destrenzan a las nubes. Despedazar celajes flotantes, será mi obra de heresiarca ${ }^{9}$.

Mirad al leñador: va solo al bosque. Cuando humedece la aurora sus sandalias de rosa en el rocío. [...] Sus plantas de conquistador van oprimiendo el suelo y brota la yerba olorosa donde puso su pie. [...]

\footnotetext{
${ }^{6}$ El canto de las horas, p. 45.

${ }^{7}$ Ibid., p. 47.

8 «Mi corazón iconoclasta», El País, 16 enero 1901.

- Loc. cit. Esta y la cita anterior se toman de María E. Dengo, op. cit., p. 51.
} 
Penetra en el bosque, hiriendo en la corteza a los árboles: el silencio se descuelga de las ramas y se pone a escuchar la resonancia metálica del cuchillo en el bosque. [...] Es ese hombre de pecho robusto y de puños fornidos como un hijo de la selva en rebelión. [...].

Así es como trabaja el leñador. Confiado en sus fuerzas se marcha al bosque y cuando le fastidian los senderos o cuando le son inútiles, se abre él mismo el suyo, con sus puños de acero ${ }^{10}$.

Lleva Arión los tesoros que ha ganado cantando en Tarento.

I la gente del barco lo sabe

Arión - le grita un marinero- muere

a puñal o en las fauces de la onda:

-iAbismo o puñal! No hai otro

camino que darte, cantor de Corinto.

—iPues dadme la mar!

Y mientras allá en lontananza

en la sombra se pierde la nave pirata

va el delfín, sobre un agua de plata

conduciendo en el dorso, contra la ola i el viento, el único bien del artista, el talento, coronado de eterna, de inmortal esperanza.

( La aventura de Arión», pp. 61 y 55)

Así como un tallo recto coronado de azucenas enmedio de ellos el ave rara levantó su canto; se irguió mucho, mucho, tanto que los pájaros sordos i salvajes rompieron a sus arpas los cordajes para azotar i desterrar al ave cuya grave, profunda melodía, aquel pueblo de pájaros salvajes no entendía, no entendía.

(«El Ave rara», p. 95)

Fustigaré la espalda del oprobio, pondré mis plantas en la torre altiva de la insolencia real i oiré sus gritos temblantes, como andrajos de bandera.

(«Juan y Jesús», p. 56)

10 «Sermo Laico», La Aurora, 26 noviembre 1904 (incluido en María E. Dengo, op. cit., pp. 316-317). 
Pero aún me siento obligado a transcribir, antes de cerrar este instantáneo acercamiento al crítico iconoclasta, un ejemplar en que el teórico es poema, y no literato, en que el poema es idea crítica, revolución destructora del pasado; «es — dice el autor- la revelación de mi posesión y dominio de la armonía del verso». En realidad, según las efemérides costarricenses de la época, fueron recibidos con brutal y burlesco rechazo poema y autor por «los barqueros rezagados de la luz». Me refiero a «Marina poniental»:

Hay un olor de yerbas

suspenso en las barbas sedosas del viento

salado del mar.

El verdor de las pálidas conservas

aceita el pelaje del rebaño de olas cuyo acento

es un perpetuo balar.

Alas de nubes rotas

cansadamente reman y se ahogan

en el azul del mar y en el celeste azul.

$Y$ entre esos dos abismos descansan las gaviotas

meciéndose en la hamaca de las ondas, mientras bogan

los crepúsculos-barqueros rezagados de la luz (p. 159).

En los fragmentos transcritos anteriormente late una constante intención crítica del iconoclasta, como puede, a la luz de la prosa, atisbarse en los registros poéticos unas veces más explícitamente que otras: «El hijo de la selva en rebelión»; «lleva Arión los tesoros», escapando y dejando atrás a los que tratan de desviarle de su amada inspiración; «en la sombra se pierde la nave pirata»; «el ave rara» entre «aquel pueblo de pájaros salvajes».

$* * *$

Los estudiosos de Brenes Mesén, al parecer se quedaron extasiados por la forma y la belleza de sus secretos símbolos. Y si alguna vez tratan de correr el velo de la idea, se detienen dándole vueltas al velo, dejando escapar la idea. En Evolución de la poesía costarricense ${ }^{11}$, a partir de la pregunta: «¿Qué 1leva a Roberto Brenes Mesén, en su libro [Pastorales y jacintos], de 1917, a pensar en el regreso de 'los dioses', cuando en esa década todavía no se piensa en este tema apasionante del realismo mágico y que sólo surgirá varias décadas más tarde?», Alberto Baeza desarrolla

${ }^{11}$ San José: Ediciones Costa Rica, 1978, pp. 94 y ss. 
varias páginas de mera especulación sobre posibles fuentes y semejanzas, que el crítico podría haber evitado si hubiese recorrido, para su análisis, Crítica americana ${ }^{12}$, al encontrarse con la bellísima pieza titulada «Los dioses vuelven», sobre Raíz salvaje, de Juana de Ibarbourou. En este ensayo, de marzo de 1905, además de lo declarativo del título, se puede apreciar, sin comentarios, uno de los bordones fundamentales de toda el arpa literaria filosófico-poética brenesmesénica: el misticismo y sagrado panteísmo pagano: «Emanaciones de místicas resinas sentíanse en su palabra y mientras más se abrían las profundidades de su pensamiento religioso más se elevaba su sentimiento hacia esa atmósfera de poético panteísmo que es al mismo tiempo la majestad y la fuerza invencible del paganismo.» Brenes Mesén califica a Juana de «fragante dríada» de una belleza natural y primitiva que está por ello «más cerca de los dioses»; «es la dríada - dice- que se ha salido del corazón de joven encina para vestirse de carne y disfrutar de majestad humana» ${ }^{13}$. $Y$ en el último párrafo del ensayo reitera: "Los dioses desterrados vuelven. $Y$ el nombre de esta poetisa habrá de recordarse así por la belleza de su ingénita poesía como por esta precursión significativa que hace de ella, para generaciones por venir, el heraldo de los dioses que retornan.»

Este bordón del alma y convencimiento de un hombre que no dudó en llamarse, contra todo convencionalismo, "hijo del amor», no cesará de sonar, desprendiendo armónicos acordes de las más puras vivencias sagradas recogidas del prístino Panteón de la Naturaleza, que manifiesta su vida en la interrelación anímica de cada ser. Poco antes de que volaran las cenizas de su frágil urna humana, nuestro autor, situado en las laderas literarias entre la llanura del ensayo y las cumbres del Parnaso, vuelve a pulsar con energía el sacro panteísmo, cuyos acordes hacen vibrar el templo místico de la Naturaleza, en su poema Rasur ${ }^{14}$. En una carta dirigida a su hija Fresia comienza, después de los saludos: «Vengo del jardín oloroso a romero y a ruda, y a sol y a cielo azul para poner en sus oídos una palabra de amor [...].» Esta palabra es Rasur. El alma brenesmesénica, enamorada y seducida siempre por la belleza al modo de los dioses niños (Krishna, Adonis, Tamuz, Attys, Horus), se encarna literariamente en Rasur, y pasa en una de esas noches estrelladas, sin que nadie la advierta, «sino el astrónomo atento y desvelado». En Rasur...

${ }^{12}$ San José: Ediciones del Convivio, 1936.

${ }^{13}$ Ibíd., p. 152. Creo conveniente advertir que B. M. publicó en 1928 veinte poemas bajo el título Los dioses nuelven, y que el primero de los veinte también lleva por título el mismo nombre.

${ }^{14}$ Rasur O Semana de Esplendor (San José: Trejos Hnos., 1946). 
[...] las voces de las dríadas

más bulliciosas son que las del viento;

casi se entienden sus palabras glaucas

bien enredadas en zarcillos vivos

de cabelleras trepadoras

que se alzan a las cumbres (p. 10).

[...] Las hamadríadas

ciñeron a sus labios las trompetas

ocultas en las rondas

y se escuchó la música del viento

graciosa y con sentido

de humanidad y juventud en ella.

Las dríadas que enseñaron al árbol

me enseñaron a mí, y a vosotros

os instruirán, si obedecéis su voz (p. 20).

El [Rasur] nos hace comprender las voces de la noche

que se confunden con los rumores de los árboles

y los ruidos de las bestias en trajín de caza;

Esas voces son los pensamientos de los dioses

de la Naturaleza que el Griego llamó PAN;

ellas originan la renovación del mundo (p. 46).

Cada uno de vosotros en la tierra

conserva una deidad

en el mundo interior que llamáis cielo;

ella es la que elabora las imágenes

que la imaginación os hace ver

en horas de creación (p. 79).

En el epílogo de Rasur, intitulado «Postrera voz del coro», Brenes Mesén reitera los ecos de este místico panteísmo pagano:

La poesía ha traído a todos los dioses conocidos a la tierra. Los himnos, las profecías, las parábolas y los cánticos de los libros sagrados de la humanidad alzaron a los hombres a las colinas espirituales, desde donde se puede ver mejor el esplendor de los dioses y oír más castamente su sabiduría divina.

Y en la citada carta a Fresia, antes del saludo final le advierte: «Le mandaremos unos pocos ejemplares para que los distribuya entre gente joven capaz de comprender la aparición de un dios nuevo» ${ }^{15}$.

${ }^{15}$ María E. Dengo, op. cit., p. 177. E1 trato de usted es todavía frecuente en Costa Rica entre padres e hijos. 
En nada se diferencia aquel rasgueo del arpa divinamente pagana subrayado por nuestro autor en la crítica a la dríada Ibarbourou, de las anímicas fuerzas sagradas que se convierten en otros tantos Rasures, dioses jóvenes, confundidos entre dríadas, hamadríadas y pánidas, habitantes del gran templo natural, libres de hornacinas y dispuestos a reencarnarse en los corazones siempre jóvenes que escuchan la voz eterna de la Belleza y del Amor.

$$
* * *
$$

En los dinteles del libro El canto de las horas, aquellas teofanías instantáneas y como premonitorias de que, algún día, su cuerpo terreno daría entrada a la divinidad que llamaba a su puerta, se convierten en la realidad bulliciosa que le hace escribir en un llano elevado, para terminar en las cumbres del poema. Ejemplos de las premoniciones teofánicas se encuentran ya en poemas de En el silencio, tal como en «La visión de la hora»:

De pie, mirando hacia el jardín, la dama blanca era una visión encantadora, un manojo de azahares en la rama del limonero en flor; era una Hora.

Soi la Hora silenciosa de la tarde que viene a derramarte en tu aposento los lirios de su amor i tú, cobarde, no conoces el lirio de mi aliento.

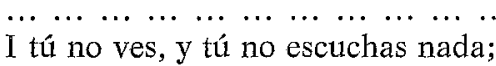

a tu lado me estoi i no me sientes, soi la Hora de la Tarde enamorada que mira despreciados sus presentes.

I te amo, $\mathrm{i}$ vengo, i no te encuentro mío; siempre estás en la sombra de tu estancia bebiendo en el cristal del libro un frío licor sin vida, endonde no hai fragancia (p. 33).

Compárese, si no, con el siguiente fragmento del prólogo a El canto de las horas:

Partía la nave del Crepúsculo: rumor de adioses perfumaba las postreras palabras de la tarde. [...]. 
Vagaba meditando por eî campo, y comencé a subir la falda de una colina. A medida que ascendía fui sorprendiendo, por entre los murmullos confusos de la Naturaleza, algo como los últimos dulcísimos fraseos de la tarde o primeras confidencias de la noche. [...] Y las voces se alzaron más sonoras, más distintas: eran las palabras de las fuentes que despertaban al pie de la colina. $Y$ ha sido para mí una encantadora noche de amor, porque las bellas e inspiradas Horas vinieron a reposar en torno mío.

Dialogaron la Aguas y las Horas en mi presencia, y yo escuché. Mis reflexiones se alejaban en la rumorosa frescura de las Aguas y volvían con el alegre vuelo de las Horas. [...].

Cuando regresé a mi hogar, al quedarme en silencio para evocar el recuerdo de las palabras de las fuentes, volví a escuchar, junto a mí, el misterioso canto de las Horas.

He tornado muchas veces a la sacra colina de la meditación [...] para sentir en el sereno bosque de mi alma la inefable armonía del canto de las Horas.

Aquí está la letra muda de ese canto; la melodía está en mi corazón y está en el Universo.

Efectivamente, en el ensayo se encuentra la letra menuda, y no tan menuda; la letra grande se halla en los poemas:

Ha venido a mí el contento

en la danza de las Horas:

ya son treinta las auroras

en que ardió mi sufrimiento.

(«En la senda», p. 200)

Las Horas, divinidades de las estaciones del año, son las que rigen el tiempo y —en la concepción religiosa griega - abren y cierran las puertas del Olimpo. Según la interpretación hesíodica, las tres hijas de Zeus y Temis llevan por nombre Eunomía (Buen Gobierno), Dike (Justicia) e Irene (Paz). La transmisión pindárica hace de Las Horas un paralelo o duplicado de Las Gracias. En general, representaban, para los antiguos, todo lo que los dioses envían al mundo en el momento oportuno, a su debido tiempo; ellas hacían brotar las plantas, aparecer las flores y madurar los frutos. Pero en Brenes Mesén, las concepciones paganas sobre las divinidades no están usadas como símbolos vacíos y ornamentales, sino como algo más; son seres anímicos divinos, con poderes, acciones y destinos trascendentes; su realidad ultrasensible sólo encuentra lugar en el 
silencio interior del hombre. En «Preludio», obertura para su libro ya citado, Poemas de amor y de muerte, dialoga el autor con las augustas y celestes divinidades bajo la modalidad de las Auroras, sobre el dolor de la muerte y la certeza de la inmortalidad:
A veces me visitan
a espalda de la Noche
las Auroras
que vienen a enjugar
el llanto de mis ojos.

$$
* * *
$$

Desde El canto de las horas se puede ascender sin comentarios a Voces de soledad; es como si la llanura literaria, producto de una intensa y prolongada reflexión íntima, en el retiro de una vida interior, se moviera hacia las alturas tomando posición de clivosa ladera ascendente, propiciando la construcción de estados de conciencia intermedios, cada vez más desprendidos de lo corpóreo, hasta llegar a la sétima morada. Con el instintivo vuelo de la abeja, o con el oscilante aleteo de la mariposa, recorreré este bosque brenesmesénico, apoyándome en los frutos del pensamiento para revolotear en busca del sutil polen de lo florido:

La obra creada se destina a los hombres, pero la creación la hace un dios en sus días de soledad y por el amor de crear. Es un santuario tallado en el blanco mármol del silencio, la soledad; y en sus altos e historiados ventanales aparece y se refleja nuestra imagen: la soledad nos pone delante de nosotros mismos y con frecuencia somos dos: el que ve y afirma y crea; el que razona y admira la creación, sin comprenderla bien, a veces. [...].

Se entra en la soledad, como el león en el desierto: para ser señor de sî ${ }^{16}$.

Está en la Soledad toda grandeza

$\mathrm{y}$ en el silencio augusto el alma fuerte;

tan sólo en el Silencio se oye el canto

de la vida viniendo de la muerte.

$\mathrm{Y}$ en el Silencio, alto como un templo, arden del pensamiento los fulgores, como en los ventanales historiados se incendian los santos de colores.

(«Soledad y silencio», p. 149)

\footnotetext{
${ }^{16}$ El canto de las horas, pp. 51-52.
} 
Sospecha el mundo que aquel hombre guarda un secreto en su vida, porque hay una extraña reserva en sus maneras; pero él calla, porque siente que no sería comprendido. De allí su lenguaje simbólico en piedra, en pintura y en la poesía ${ }^{17}$.

Alma viril, en tu secreta sombra

vive plantando las esbeltas palmas

de tu interior jardín, mientras la injuria

falso y demente y desertor te llama.

(«Hora de tormenta», p. 148)

En la soledad amo el rayo de la luz y la flor y el animal, porque en ellos miro una fuerza espiritual que me invita a ascender a los planos superiores del Universo; son la expresión evidente de las corrientes de la Vida invisible que cambia la acidez de la fruta naciente en la suavísima y perfumada dulzura de la madurez ${ }^{18}$.

Es el hada que trasmuta

la amargura y la acedía

en almíbar y alegría

para el alma de la fruta.

(«La fruta», p. 195)

Pensamiento de la rama

Con los ojos hacia arriba

en la luz sus jugos liba

para el hada de su gruta.

$\mathrm{Y}$ admirada o escondida

el esfuerzo de su vida

es para cambiarse en fruta.

(«La flor», p. 194)

No es soledad la del desierto sino la de la ausencia de las almas. [...] Hay en la bellísima quinta del alma un rincón de desierto en donde a veces nos visita una atrayente deidad, una vehemente Salomé, ataviada de transparentes encajes: la encantadora Tentación. Allí llega a hablarnos de triunfos y de oro, de senderos de laurel; de mirra e incienso de gloria, de Venecias de amor ${ }^{19}$.

${ }^{17}$ Ibid., p. 53.

${ }^{18}$ Loc. cit.

${ }_{19}$ Ibid., pp. 54-55. 
Soledad de rubia arena con silencios de desierto nada más ante sus ojos, nada más ante su mente de severo anacoreta, en su joven vida muerto para el mundo de ilusiones que seduce, encanta y miente.

(«En el desierto», p. 155)

Por una vez, sólo por ésta, voy a salirme de la espiral del tiempo sin calendario en que estoy considerando la obra de Brenes Mesén. Mirando de reojo hacia la cronología de la historia, los anteriores fragmentos, contrapuestos, pueden confirmar que toda la creación de nuestro autor va pasando cíclicamente por tres estadios: el retiro y soledad, durante un prolongado silencio, para ir acumulando gota a gota el destilado licor de sus meditaciones. Después, cuando da rienda suelta al amplio caudal acumulado, nace el escrito de renglón largo y apretado párrafo, con el que el autor retroalimenta su pensamiento, que sale convertido finalmente, en la quintaesencia de su sentir, torneado con las formas del poema. El canto de las horas salió a la luz en 1911; los poemas de Voces de soledad y Voces del ángelus, que con él dejamos confrontados, se publicaron unos en 1913 y otros en $1916^{20}$.

$$
* * *
$$

Bajo el título «Ley de obediencia al Maestro» desarrolla el último de los tres ensayos que integran el libro El canto de las horas. Me ha parecido tan evidente la transición que existe entre este escrito y varios de sus poemas, que sin ninguna duda lo tomo como umbral, vestíbulo y gradas que acercan a otros registros. Ya desde el título se advierte la antítesis de la insistentemente preconizada libertad del artista. Y, en efecto: Brenes Mesén asienta, defiende y prueba que para ser libre se deben primero desarrollar las alas de la libertad que se persigue a la sombra luminosa de la obediencia al Maestro.

Una vez más entraremos a las vivencias místicas del poema, ascendiendo por los peldaños del ensayo. En realidad, siguiendo este camino encontraremos al autor aflojando por sí mismo los a veces herméticos cerrojos de sus poemas. Trato de evitar, en todo momento, convertirme en salteador proclive a manejar ganzúas y llaves maestras para violar lo ajeno. Como es mi propósito en todos estos acercamientos, quedará abierto, en mayor o menor grado, el cofre del poema, con las propias llaves de su autor. Así, en los inicios del citado ensayo ${ }^{21}$ :

${ }^{20}$ La cronología crítica de la obra de B. M. no se ha hecho todavía.

${ }^{21}$ Ibid., p. 63. 
El amor de la libertad armó el brazo altanero de la rebeldía para dar muerte a la obediencia. [...].

La obediencia es dulce; nos deja sentir nuestra venturosa dependencia de las leyes del Universo y de los lazos de amor y armonía de los hombres.

Continúa la discursiva defensa sobre su tesis, pero a intervalos frecuentes la interrumpe con invocaciones:

Dulce y sabio Maestro, condúceme. [...] Dulce y sabio Maestro, guíame. [...] Dulce y sabio Maestro, te amo infinitamente. Y así como ahora tengo depositadas las azucenas de mis manos en las tuyas, así, con el mismo amor, depondré en el ara de tus obras los geranios de mi antiguo orgullo y los altos lirios de mis aspiraciones ${ }^{22}$.

Señor de Amor, mi lámpara votiva sobre la urna de cristal de mi alma consume los aceites de mi vida, la esencia de mi ser en limpia llama.

$Y$ vierto en su fulgor, como un incienso, los vasos de perfume del pasado para mirar, quemando, los recuerdos que en otro tiempo acaricié por santos.

$$
\text { («La ofrenda», p. 171) }
$$

En este primer movimiento se manifiesta el asceta que purga su existencia, ofreciéndose como lámpara votiva. En los siguientes pasajes se aprecia la invocación y vislumbre de la presencia del Maestro.

El Maestro es un ideal de la perfección en el Arte. [...] Una mirada strya, la sola contemplación de una obra suya nos consuela, nos alienta y en los labios amargados del desencanto vierte el licor fortificante del estímulo; [...] cuando se va acercando a nosotros la sonoridad de sus pasos pone un tremor delicioso en el pavimento de nuestra alma ${ }^{23}$.

Maestro, ven que tu sutil presencia se derrama en los ámbitos de mi alma como un perfume de exquisita esencia, como un grato rumor de selva y agua.

A veces junto a mí, sin luz, te siento venir como vibrante sinfonía; hasta el limpio silencio de tu aliento inunda mi existencia de armonía.

(«A mi Maestro», p. 172)

${ }^{22}$ Ibid., pp. 65-66.

${ }^{23}$ Ibíd., loc. cit. 
En «Erudición y arte literario», último de los ensayos de su Crítica americana, se expresa de manera semejante:

Las obras maestras de la literatura alientan y tienen su ser en la luz primaveral de la inmortalidad. [...].

En cada obra maestra yace, como en una emboscada, el prometeico espíritu del fuego que lleva las llamas a la pira, grande o pequeña, de nuestro propio genio. Es como si se nos arrastrase a los jardines elíseos de nuestra imaginación creadora, en donde volvemos a representar nosotros las concepciones del poeta; en donde, como arrebatados, escuchamos esa recóndita música que impone un rito mágico al corazón palpitante de todas las cosas en torno nuestro ${ }^{24}$.

Como en la noche oscura de los místicos - y Brenes Mesén lo es por testimonio literario y vida-, declara la amargura de su alma porque la ausencia del Amado to deja desvalido entre las sombras:

Cuando se aleja, en todas las arboledas de nuestro interior se levantan los rumores quejumbrosos de la ausencia y de la noche ${ }^{25}$.

¡Vaso de amor! ¡Estrella mía! ¡Cuánta sombra ha caído en la apacible senda encendida de rosas y jazmines que me llevaba a ti, sin esta tienda de amor ni de dolor que el mundo ha abierto enmedio de los vírgenes jardines de mi alma, iluminada con tu sombra!

¡Cuán pronto se apagó tu casta lumbre dentro de mí! ¡Cuán pronto la querella de mi alma subió hasta tu cumbre a pedirte que encienda tu mirada mi lámpara votiva a la constancia para emprender de nuevo la jornada! («Lámpara votiva», p. 174)

Y cuando después de la «noche oscura» se hace presente ese Señor de Amor, ese Maestro, ese Vaso de Amor, esa Estrella, esa Luz tan deseada e invocada, como premio de una intensa búsqueda, espera, y obsequioso seguimiento a la Ley, el alma se llena de contento y se ilumina la morada:

${ }^{24}$ Op. cit., pp. 183-184.

${ }^{25}$ El canto de las horas, p. 67. 
La vida tiene el encanto de una rosa de luz hecha perfume en nuestras manos, nos envuelve al maravilloso fulgor de una callada aurora de felicidad bendita e izando sus velas el alma, navega en el océano de lo Infinito y lo Inmortal.

Una sensación nueva, como una princesa recluida largo tiempo en nuestro corazón, sale y llena con el hechizo de su belleza y de su alegría todos los parajes florecidos de nuestra conciencia [...].

El Dante no pudo llamar esa sensación más dulcemente, «Beatrice» $[\ldots]^{26}$.

Idénticas vivencias de este contento por la presencia del amado se encuentran en los siguientes fragmentos de varios poemas:

Cuando callo, pensabundo

siento en mi alma el aleteo

de la luz del Padre Zeo

que ilumina el mar profundo.

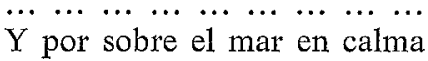

blanca vuelve, blanca a mi alma,

bajo un sol de primavera.

(«El ansia blanca», p. 203)

$Y$ hubo entonces como un vuelo

de potestades del cielo

saludando un Ser Divino.

(«Peregrino», p. 204)

Cómo, en la capilla muda,

la divina voz de Budha

habla de misericordia.

Y en la villa o la caverna

me enseñó a adorar la eterna

ley de Amor y de Concordia.

(«La siempre amada», p. 208)

$\mathrm{Y}$ al morir, como devoto

de Isis, vi nacer un loto

blanco en mi alma, siempre eterno.

(«La siempre amada», p. 208)

${ }^{26}$ Ibid., p. 30. 
Vibraciones semejantes se pueden sentir en «Voz interior», en «En la senda», en «Peregrino», en «iOh bello arcángel!», en «Triunfaré», en «El fuego» y en muchas otras estancias de su poesía.

En los poemas «La prueba del agua», «La prueba del fuego» y «Ante Beatriz» se aprecia claramente, entre ellos, un paralelismo de desolación, penitencia, ascetismo, ruego por la presencia del Maestro y, al fin, vivencia mística por la aparición del Amado. Los tres poemas manifiestan a la luz de la obediencia al Maestro como temática, al modo de sendos epítomes biográficos:

El dolor hizo aposento

en mi cámara secreta;

mi agonía oró, discreta, sin que se oyese un lamento.

Cuando el ángel de tormento vistió a mi alma de bayeta, amé el ser anacoreta sin ningún remordimiento.

$E$ invoqué la paz del cielo con el más ardiente anhelo que jamás sentí, ni he visto.

$\mathrm{Y}$ de pronto, sobre el manto de agua amarga de mi llanto vi cruzando al dulce Cristo (p. 212).

Se incendió el pinar entero de mi juventud pasada; fue como un castillo de hada sobre el oro de un brasero.

Entre 1lamas, sin sendero, mi pobre alma desolada se lanzó a correr, 1levada por algún poder austero.

Ante el resplandor del fuego elevó hasta Dios un ruego y cayó de hinojos, muda.

$\mathrm{Y}$ de pronto, entre dragones, sobre llamas y carbones, vino hacia ella el manso Budha (p. 213). 
Derramé sobre la Ciencia

todo un cántaro de vida;

una lámpara encendida

fue ante el Arte mi conciencia.

Del raudal de mi paciencia

la mitad dejé vertida

en la arena florecida

de una efímera sapiencia.

Luego, al madurar el día, se hundió en la Filosofía

toda mi ansia de estudiante.

$Y$ hoy, al fin de la carrera, postro mi alma en primavera

ante la Beatriz del Dante (p. 222).

En «Amado del alma» se advierten todos estos ecos que salieron unidos de la pluma del Santo en el lenguaje clásico de un místico, cuya confesión religiosa comprende e invade el ámbito de lo universal:

Por todos los senderos

de esta callada selva

pasar te he visto, iAmado

del Alma, a quien venero!

Por todos los senderos

de esta callada selva

te voy siguiendo, Amado

Maestro de mi vida, para tenderme un día

delante de tus pasos

como un riachuelo puro

que canta de alegría

sintiendo en sus riberas

un rumor de palomas

y un temblar de palmeras (p. 226).

Pero sobre un grueso bordón fundamental entorchado con hilos de metafísica, cosmogonía, filosofía y teodicea, descansa construida la obra hecha vida y la vida hecha obra de Roberto Brenes Mesén. Todos los 
armónicos concomitantes o sucesivos, que forman temáticas, o paratemáticas mejor, en la obra brenesmesénica, están construidos sobre este bordón angular que él pulsó reiteradamente con las mismas palabras y contenidos del verso cosmogónico virgiliano, saliendo de la boca de Anquises, tan grave en el ritmo como en la idea:

\section{totamque infusa per artus}

mens agitat molem et magno se corpore miscet (En. VI, 726-727).

que interpretamos.: ... Y difundida por sus miembros y articulaciones, una mente agita toda la materia, mezclándose con el ingente cuerpo.

En el ya citado ensayo «Los dioses vuelven», de su Crítica americana. (p. 135), después de comentar y citar el Timeo, de Platón, para probar la concepción monista y anímica de la organización cósmica, continúa Brenes Mesén traduciendo la primera parte del verso 727 de la cita virgiliana: "Hay una mente que agita la materia», que en el referido texto platónico equivale a «el mundo se hizo alma viviente y verdaderamente racional»; y prosigue nuestro autor: «una sutil inteligencia mora en las oscuras raíces de todos los árboles».

En El canto de las horas (p. 20) recurre a este fundamental concepto. de su obra: « ¡El alma de las cosas!»:

La mente agita la materia. La vibración alta y poderosa del Alma del Mundo respira sutilmente en el interior de todas las formas. En las aguas infinitas de la vida, sin fondo y sin riberas, surgen unos en pos de otros universos, como brotan del cielo de la tarde, unas en pos de otras, las estrellas. [...] Es la vida, el Alma del Mundo, la que ejercitando su presión sobre las formas, las hincha, las sutiliza, las rompe y esa vida se desborda en formas nuevas más amplias, más flexibles, más perfectas, constituyendo, de esta suerte, la fuerza secreta, poderosa, de la evolución.

$Y$ en la p. 42 vuelve a sentirse el eco de este como obsesivo pensamiento brenesmesénico; cuando en palabras de Wordsworth, escribe: «... hay en la mente del hombre un impulso y un espíritu que impele todas las cosas pensantes, todos los objetos del pensamiento y gira a través de todas las cosas».

Hasta en $L a$ voluntad de los microorganismos ${ }^{27}$, de corte cientificista, se rastrea semejante concepción infusa en todos sus escritos, cuando opone a la teoría mecanicista de los tropismos el evolucionismo por la intervención de fenómenos psíquicos:

\footnotetext{
${ }^{27}$ San José: Imprenta Alsina, 1905, p. 5.
} 
E1 yo quiero - escribe- como declaración efectiva de la voluntad, se traduce por movimientos molares indispensables para realizar ese «yo quiero»; como simple idea supone movimiento molecular de las corrientes nerviosas que son la base de todo fenómeno síquico.

Toda la exposición del ensayo está fundamentada en los movimientos molares o moleculares, es decir, en el «mens agitat molem». Con razón, en «Itinerario» ${ }^{28}$ rechaza las acusaciones que sus coetáneos le hacen contra supuestos cambios radicales en las opiniones expresadas: «Pero ha sido frecuente que se juzgue cambio repentino lo que simplemente ha sido una ampliación de una misma manera de pensar [...] ¿Cambio? No, una sencilla consecuencia $[\ldots] »$.

De una manera más explícita se vuelve a encontrar esta alimentadora idea central de su obra en Metafísica de la materia ${ }^{29}$ :

Tal material mental es energía potente que constituye la esencia de la materia astral; la que a su vez, lo es de la materia física, ya que es la esencia del éter. No hay, por lo tanto, solución de continuidad desde la materia mental hasta la materia física. $Y$ tal es un primer profundo sentido de las palabras de Virgilio: «la mente, difundida en las venas del mundo, agita la masa de la materia y mezclándose con ese vasto cuerpo» (... totamque infusa per artus mens agitat molem et magno se corpore miscet). La esencia de lo que llamamos el Universo real es la mente $[\ldots]$.

Enfrentando la concepción racionalista, en su meditativo y central ensayo El misticismo como instrumento de la investigación de la verdad ${ }^{30}$, vuelve a pulsar el bordón virgiliano, no sin aclarar que ante esta concepción monista y espiritual, la conciencia personal no se pierde difuminada en un panespiritualismo, sino que, al contrario, queda subrayada y enriquecida: «Se es parte —escribe- de la mente que agita el universo. Lo cual no significa pérdida de nuestro yo, sino la exaltación de nuestra conciencia...» Como vibración literaria de todo este pensamiento, en el más sutil grado de ensayo, se me ofrece el poema «Mens agitat molem»:

¿Cuál es la fuerza que llevó el botón

a abrirse en flor,

la fresca flor a madurar en fruto

y el fruto al polvo?

${ }^{28}$ Claudia Cascante, Antología poética de Brenes Mesén (San José: Ministerio de Educación Pública, 1959), pp. 18-19.

${ }^{29}$ San José: Imprenta Lehmann, 1917, p. 54.

${ }^{30}$ San José: Imprenta Alsina, 1921, p. 42. 


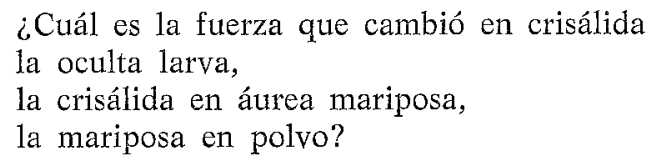

¿Cuál es la fuerza que conduce al niño hacia el umbral del hombre, y al hombre adulto a la vejez de armiño $\mathrm{y}$ el viejo al polvo?

La bella flor, la mariposa de oro, el hombre mismo es sólo el vaso que contiene una divina emanación de vida.

La forma es tierra y se disuelve en polvo: el alma eterna que la agita es todo (p. 264).

$* * *$

Aquí cierro estas aproximaciones literarias, consciente de que he caminado, leyendo y releyendo con entusiasmo no apriorístico, sino experimental o experimentado, la obra de Roberto Brenes Mesén. Lo que sinceramente siento al escribir estas últimas líneas, como balance final, me provoca una sensación de contento insatisfecho. El contento me lo ha proporcionado la sinceridad hermosa y cristalina con que el autor visitado ha ofrecido a mi vida en cada rincón de su obra; la insatisfacción me nace al tener presente lo poco que quizá haya podido compartir con el lector de lo mucho que he sentido. Esto mismo me lleva a considerar el tratamiento de las anteriores páginas como simples escarceos que me han planteado (y tal vez también al lector) las múltiples facetas sorprendidas en la obra unitariamente considerada de Brenes Mesén, para un estudio de más amplitud y envergadura, que reclamará una larga dedicación, sin duda alguna fructuosa y feliz.

Solamente me resta presentar un mínimo desfile de las más sobresalientes contingencias existenciales de nuestro autor, con el restringido intento de dar una breve noticia, no para el estudio de su obra. Porque un hombre como Brenes Mesén, sin duda alguna prefirió, mientras sostuvo aliento y luz en los ojos, ser seguido que aclamado; y, por consiguiente, su obra persiste flotando, casi sin rozar, sobre el maremágnum contingencial que se entreteje en torno de su figura. Sobre cualquier humano, con el recorrido de varios decenios de vida, nunca falta multitud de circunstancias que narrar, acaecidas, la mayoría de las veces, sin la intervención 
voluntaria del protagonista. Y Brenes Mesén no persiguió ser primer actor o agente ante nadie, sino, como expresa el David de su Rasur, "ser el señor de sí / señor de los relámpagos del aire, / después de dominar las tempestades / del propio corazón».

Nació en San José en 1874. Tres lustros más tarde había cumplido los estudios de secundaria, con algo más de lo que expresan los créditos sobresalientes de la academia. Dos años más, y se le confiere el título de Maestro Nacional. Durante su adolescencia y los primeros años de su juventud en el ejercicio del magisterio, tuvo entre sus compañeros asiduos de lectura a Renán, Shakespeare y Víctor Hugo; igualmente le acompañaron Epicteto, Marco Aurelio, Plotino, Lucrecio, Humboldt y numerosas obras de los griegos y latinos; en pedagogía se contentó con la lectura de Spencer y de Rousseau. De la literatura castellana prefirió los clásicos de los siglos xvi y xvir. Períodos hubo en esta época, y en otras de su vida, dedicados a una ruda labor de estudio, meditación y creatividad literaria, tan intensa que apenas si dormía seis horas diarias. A sus veintidós años de edad podía algo más que leer francés, inglés, italiano, latín y griego; estas dos últimas lenguas, junto con el sánscrito, las perfeccionaría más tarde.

La segunda etapa de sus estudios formales superiores, que dura desde 1897 hasta los primeros meses de 1900, tiene por escenario el Instituto Pedagógico de Santiago (Chile). Fecunda fue su estancia en tal institución, desde donde mantiene correspondencia con Rubén Darío, quien le conduce a la obra de Lugones. Con el profesor Hansen, la filología indogermánica le suscita interés por el estudio del sánscrito, que le conducirá a las literaturas orientales. Participa activamente en el «Ateneo» de Santiago con presentaciones y declamaciones de sus poemas y ensayos literarios.

De nuevo en Costa Rica, con veintisiete años de edad, estrena, se puede decir, el siglo actual con intervenciones muy frecuentes en los periódicos, a la vez que ejerce el profesorado en el Liceo de Costa Rica y en otros colegios del país, dedicado fundamentalmente a las disciplinas de Castellano, Lógica y Psicología. Fue amigo, y muy admirado, de Joaquín García Monge, quien, como editor, en muchas ocasiones favoreció la publicación de sus escritos. Durante 1909 desempeña el cargo de secretario de Relaciones Exteriores; seguidamente, hasta 1913, el de subsecretario de Instrucción Pública. En 1915 imparte Psicología, Sociología e Historia de la Pedagogía en la recién fundada Escuela Normal; al año siguiente desempeña el cargo de director de este centro, sin abandonar el ejercicio docente. Junto con García Monge y Omar Dengo, pone sello a la institución, alma mater del magisterio costarricense hasta entrada la década de los setenta. 
Una cuarta etapa de su vida se inicia en 1919, con su residencia en los Estados Unidos. Durante el primer año fue jefe de la Sección de Español de Pictorial Revue de Nueva York; después, profesor de Español de la Universidad de Syracuse hasta 1925; durante este período dicta un curso en la Universidad de Columbia. Seguidamente es contratado por la Universidad de Northwestern, donde desempeña el cargo de profesor en una variada gama de materias dentro del amplio campo de la Filología Hispánica.

En 1939, año en que regresa jubilado de los Estados Unidos, se inicia la última etapa de su vída, con permanencia en Costa Rica. Alterna con su asidua labor literaria una intensa actividad de conferenciante, tanto en el país como en el extranjero, principalmente en Estados Unidos, Guatemala y El Salvador.

Como escritor, su trabajo fue intenso y continuo durante los cuarenta y siete calendarios que presenciaron el paso de su vida por el siglo xx. El balance de sus días lo dejó escrito a través de reiteradas premoniciones, en muchas estrofas de los libros de sus poemas y en muy diversos momentos de su vida. Uno de ellos nos lo dejó escrito en 1916:
Al final de la jornada que ya tengo recorrida me parece que en mi vida realicé muy poco o nada. La tormenta encadenada a la mar embravecida es la imagen de mi vida: vigorosa, pero atada.

(«Triunfaré», p. 210) 
